\title{
LARGE-SCALE SPATIAL TRENDS IN RECENT FIRN CHEMISTRY ALONG AN EAST-WEST TRANSECT THROUGH CENTRAL GREENLAND
}

\author{
H. FISCHER and D. WAGENBACH \\ Institut für Umweltphysik, University of Heidelberg, Heidelberg, Germany
}

(First received 6 November 1995 and in final form 13 March 1996)

\begin{abstract}
Seventeen shallow firn cores drilled along an $\sim 1000-\mathrm{km}$-long east-west traverse through central Greenland (EGIG-line) and dated by annual $\delta^{18} \mathrm{O} / \mathrm{H}_{2} \mathrm{O}_{2}$ stratigraphy have been evaluated in seasonal resolution for their nitrate, sulphate, chloride, sodium and calcium content covering the time span $\sim$ 1982-1992. Each component showed a geographically uniform seasonal input pattern along the EGIG-line corresponding to what is observed at other sites over the central Greenland Ice Sheet. Going across the main ice divide from west to east, the strong decline in the mean snow accumulation rate (associated with precipitating air masses advected from the west) causes a linear decrease in the average deposition rates of nitrate, sulphate and calcium with longitude. Sea-salt components, however, exhibit an exponential decline (scale length $\sim 320 \mathrm{~km}$ ) from the west to the ice divide but constant rates in the eastern part. The mean firn concentrations of all ions show a systematic increase from west to east related to the concurrent snow accumulation decline. Only exceptionally high sea-salt concentrations at the western-most positions deviate from this picture. Including results from other drill sites all over the Greenland Ice Sheet, a geographically uniform linear relationship of accumulation and deposition rates for the non-sea-salt components is observed. For nitrate, sulfate and calcium average dry deposition fluxes of 1080,610 and $156 \mathrm{ng} \mathrm{cm}^{-2} \mathrm{a}^{-1}$, respectively, are inferred which, depending on the local accumlation rate, may explain $20-40 \%$ of the total nitrate and sulphate but $40-80 \%$ of the total calcium deposition flux. Copyright (1996 Elsevier Science Ltd
\end{abstract}

Key word index: Greenland, aerosol, deposition, snow accumulation.

\section{INTRODUCTION}

Due to the incorporation of aerosol components into glaciers and ice sheets by wet and dry deposition and because of the isotopic signature $\left(\delta^{18} \mathrm{O}, \delta \mathrm{D}\right)$ in the ice matrix itself, polar ice masses represent a unique archive of past atmospheric and climatic conditions. During the last 30 years, strong efforts have, therefore, been devoted in recovering long-term glaciochemical and isotopical ice core records from the Greenland Ice Sheet (e.g. Neftel et al., 1985; Mayewski et al., 1986; Fuhrer et al., 1993; Hansson and Saltzmann, 1993).

Little attention, however, has been paid to the spatial representativeness of individual deep ice core records (Mayewski et al., 1990) and in particular little information on large-scale geographical trends in chemical snow properties (Boutron, 1979; Osada and Langway, 1993) is available. Furthermore, increased interest in microscale effects on firn chemistry like remobilisation of gaseous species (Wolff, 1995), migration during firnification (Wagenbach et al., 1994), firn ventilation (Harder et al., 1991), fog deposition (Bergin et al., 1995), etc. has given rise to uncertaintites in the straightforward interpretation of ice core records with respect to atmospheric conditions.
Therefore, a detailed knowledge of the factors controlling (net) aerosol deposition is necessary to assess the impact of such effects on the chemical firn composition. In this context, especially the glaciometeorological parameters (temperature, accumulation) are expected to exert major influence on the deposition processes, however, their relationship to the chemical firn composition is still unsufficiently known for the Greenland Ice Sheet. Based on data from different drill sites on the Greenland Ice Sheet, Herron (1982), for example, proposed an inverse relationship between accumulation and both sulphate and nitrate firn concentrations, which he attributed to substantial incorporation of these species into precipitation at gas to particle conversion of their reactive gaseous precursors. Yang et al. (1995), however, investigating small temporal changes of annual nitrate firn concentrations in cores from different north hemispherical drill sites, could not confirm such accumulation dependence. Furthermore, Davidson et al. (1989) suggest more efficient aerosol scavenging for higher temperatures in the summer months at Dye3, attributed to enhanced riming of snow flakes during that season.

In 1990 and 1992, the reconstruction of the EGIGline, central Greenland, by the Geodetic Institute, 


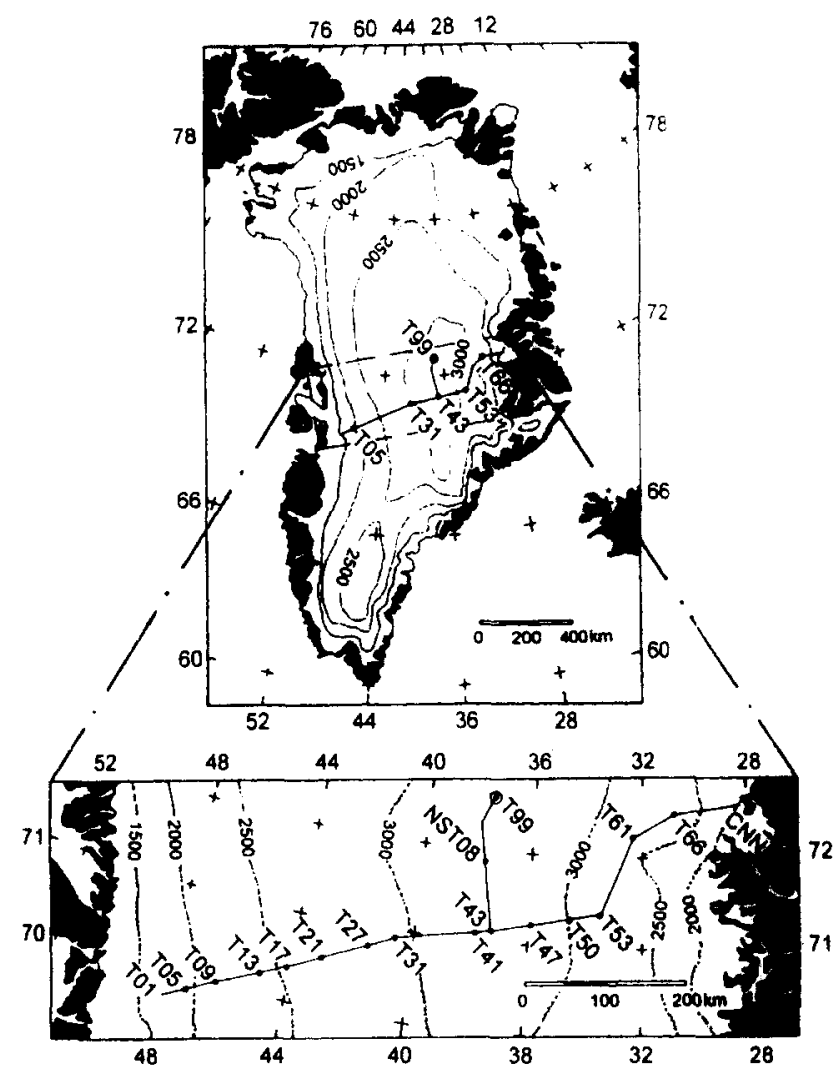

Fig. 1. Map of Greenland showing the complete EGIG-line. The enlargement shows all investigated drill sites along both traverses.

University of Braunschweig, Germany, enabled us to carry out an accompanying glaciological program. Based on shallow firn core drillings at 18 positions along an approximately $1000-\mathrm{km}$-long east-west transect through central Greenland (see Fig. 1), the seasonal and spatial variability of isotopical and glaciometeorological firn parameters over a time scale of $\sim 10$ years were investigated. Comparison of average accumulation rates and firn temperatures with previous measurements along the EGIG-line showed no significant temporal change over the last 30 years (Anklin et al., 1994; Laternser, 1994; Fischer et al., 1995). The geographical distribution of these glaciometeorological parameters as well as of the isotopic firn signature was extensively studied by Fischer et al. (1995) and suggests distinct differences between the areas east and west of the ice divide: Snow accumulation (see Fig. 2) significantly decreases from the western-most positions to the ice divide but remains essentially constant in the eastern part of the EGIGline. The $\delta^{18} \mathrm{O} / \delta \mathrm{D}$ signature along the EGIG-line also confirms climatologically different regions in the eastern and western part. Excessive isotopical depletions encountered east of the ice divide indicate a main water vapour trajectory over central Greenland from west to east. This is also documented by the snow accumulation/temperature-dependence along the EGIG-line. Here a linear decrease of average annual accumulation rates with decreasing average annual temperature (here represented by $15 \mathrm{~m}$ firn temperatures) from T21 to T43 is observed, while east of the ice divide accumulation rates remain constant despite increasing temperatures towards the east coast.

Now, we report on the chemical investigations on the EGIG firn cores concerning the major ion concentrations associated with sea salt $\left(\mathrm{Cl}^{-}, \mathrm{Na}^{+}\right)$, mineral dust $\left(\mathrm{Ca}^{2+}\right)$ and anthropogenic (or biogenic) species $\left(\mathrm{NO}_{3}^{-}, \mathrm{SO}_{4}^{2-}\right)$. Emphasis is laid here on the geographical variability over a vast region of the central Greenland Ice Sheet (at comparable latitude, see Fig. 2) as possibly influenced by

- the largely varying continentality as parameterised by distance to the coast,

- the elevation change from 1900 to 3230 m.a.s.l.,

- the range of annual mean surface air temperatures (here represented by $15 \mathrm{~m}$ firn temperatures) of -18 to $-32^{\circ} \mathrm{C}$, and

- the net annual snow accumulation covering a range between 46 and $17 \mathrm{~cm}$ water equivalent per year.

Any clear relationship between firn impurity concentrations and snow accumulation rate (latter being mainly governed by the other parameters mentioned 


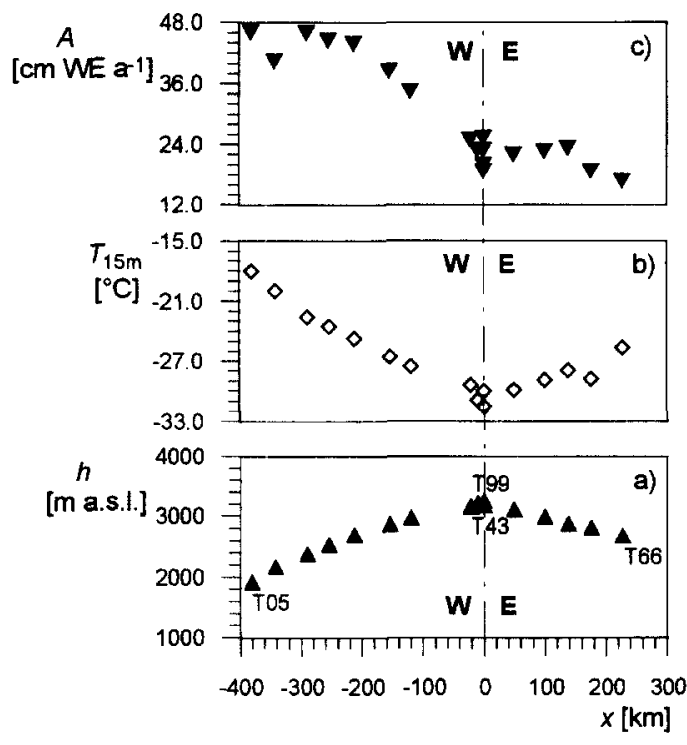

Fig. 2. Geographical distribution of average snow accumulation rate in $\mathrm{cm}$ water equivalent, $15 \mathrm{~m}$ firn temperature in ${ }^{\circ} \mathrm{C}$ and altitude in $\mathrm{m}$ above sea level along the EGIG-line.

above) appears to be most important when interpreting chemical records of deep ice cores subject to long-term changes of the local snow accumulation rate.

Both seasonal and spatial variations in firn concentrations along the transect are interpreted in this study intending

- to determine possible geographical changes in the seasonal input timing of different ionic species along the EGIG-line,

- to test the robustness of geographical trends with respect to changing climatological conditions through the course of the year, and

- to calculate regionally representative deposition rates for the central Greenland Ice Sheet together with their spatial and interannual variability.

\section{METHODS}

\section{Sampling}

Firn core drilling and pit sampling for this study was performed during two traverses in 1990 and 1992 along the EGIG*-line (Fig. 1). In 1990 (henceforth referred to as EGIG-west) ten shallow $(\sim 8 \mathrm{~m})$ firn cores were drilled and supplemented by pit studies performed en route from $\mathrm{T} 99$ (Summit/Dome GRIP ${ }^{\dagger}$ ) via T43 (Crête) to T05. In 1992 (EGIG-east) the traverse started again at T99, moved to T43 and then followed the eastern part of the EGIG-line to T66 and finally returned at Caecilia Nunatak. Along this route, eight shallow $(\sim 8 \mathrm{~m})$ firn cores were drilled and pits excavated. Additionally, high-precision temperature measurements were performed in 17 separately steam-drilled boreholes (Laternser, 1994) during this season.

* EGIG = Expédition Glaciologique Internationale au Groenland.

${ }^{+}$GRIP = Greenland Ice Core Project.
Firn cores drilled in 1992 were shipped in frozen state to Heidelberg using the GRIP cooling facilities, subsequently divided into approximately eight subsections per year and thoroughly decontaminated under clean air conditions in our cold lab using a contamination-free plane. Samples for chemical analyses were sealed in polyethylene (PE) bags six-fold rinsed with highly purified water. To check for possible contamination during sample handling, highly purified $(>16 \mathrm{M} \Omega$ ) water blank samples (process blanks) were subjected to the entire decontamination routine as well. Dating of the cores drilled in 1992 was established by counting annual layers in the firn defined by the $\delta^{18} \mathrm{O}$-profile.

Unlike for the EGIG-east campaign, cooling facilities were not available for the transport from Greenland to Heidelberg. Therefore, precautions had to be taken to ensure seasonal resolution of the samples despite sample melting and to prevent them from gaseous or particulate contamination. Thus, cores were dated in the field by high resolution in situ determination of the $\mathrm{H}_{2} \mathrm{O}_{2}$-profile (Anklin et al., 1994), using a fluorimetric method after Sigg (1990). Following, seasonal samples (2-8 samples per year dependend on the local accumulation rate) were cut according to the $\mathrm{H}_{2} \mathrm{O}_{2}$-profile (e.g. see Fig. 3). Each sample was thoroughly decontaminated in a comparable manner as in 1992 by scraping off the outer firn surface using a contamination-free plane and sealed for transport in precleaned PE bags. Samples of individual cores were subsequently put into larger closed PE storage bags. Of course, no controlled clean air conditions could be established in the field. For direct comparison of the different procedures (see below) "parallel" firn cores were drilled at position T99 and T43 during both the 1990 and 1992 seasons.

\section{Analyses}

All samples were analysed for $\delta^{18} \mathrm{O}$ and $\delta \mathrm{D}$ by mass spectrometry and with exception of position T50, where core quality was very poor, for ion concentrations by ionchromatography (IC). IC of the samples generated during EGIG-west was performed on a Dionex $4500 \mathrm{i}$ system isocratically run with a Dionex CS10 cation separator column and, using a gradient method, with an AS4A anion separator column both under chemical suppression. For the $1992 \mathrm{sam}$ ples, cation concentrations were determined using a Dionex CS12 column with autosuppression. This column, in contrast to CS10, allowed for temporally well-resolved peak detection of monovalent and bivalent cations in a single isocratic run. Accuracy of the IC-measurement is better than $10 \%$ of the sample concentration. Laboratory process blank values contribute less than $15,5,7,15$ and $5 \%$ to the average sample concentration of $\mathrm{Cl}^{-}, \mathrm{NO}_{3}^{-}, \mathrm{SO}_{4}^{2-}, \mathrm{Na}^{+}$and $\mathrm{Ca}^{2+}$ respectively, in individual cores. Therefore, no blank correction for the given concentration values was introduced.

Non-sea-salt contributions to the total sulphate and chloride concentrations were determined using sodium as sea-salt reference component according to

$$
\begin{gathered}
{\left[\mathrm{nssSO}_{4}^{2-}\right]=\left[\mathrm{SO}_{4}^{2-}\right]-0.25\left[\mathrm{Na}^{+}\right]} \\
{\left[\mathrm{Clx}^{-}\right]=\left[\mathrm{Cl}^{-}\right]-1.80\left[\mathrm{Na}^{+}\right]}
\end{gathered}
$$

where $\left[\mathrm{SO}_{4}^{2-}\right],\left[\mathrm{Cl}^{-}\right]$and $\left[\mathrm{Na}^{+}\right]$are the total concentrations measured, [nssSO $\left.{ }_{4}^{2-}\right]$ is non-sea-salt sulphate, $[\mathrm{Clx}-]$ the so-called excess chloride and constant factors are the corresponding seawater ratios of $\mathrm{SO}_{4}^{2-} / \mathrm{Na}^{+}$and $\mathrm{Cl}^{-} / \mathrm{Na}^{+}$, respectively. Since sea-salt sulphate contributes only $\sim 4 \%$ to the total sulphate level over the EGIG-line, henceforth, only total sulphate values are considered.

Samples generated during EGIG-west and shipped without cooling facilities were already melted on arrival in Heidelberg. In the closed PE storage bags of each core we found water from occasionally occurring sample leakages. To check the remaining melt water samples for contamination possibly occurring during field processing and/or 


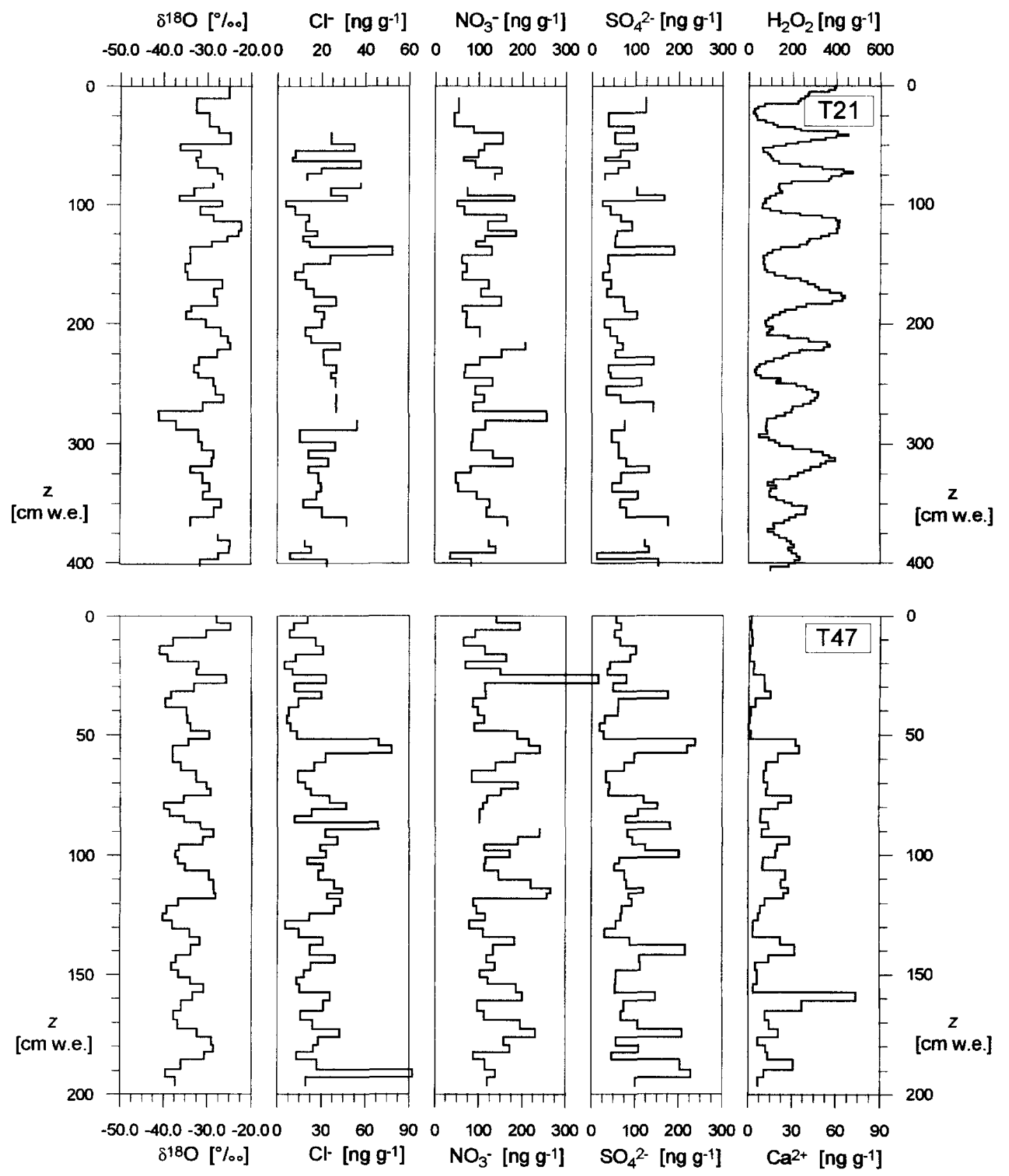

Fig. 3. Profiles of seasonal varying tracers $\mathrm{NO}_{3}^{-}, \mathrm{SO}_{4}^{2-}, \mathrm{Cl}^{-}, \mathrm{Ca}^{2+}, \mathrm{H}_{2} \mathrm{O}_{2}$ and $\delta^{18} \mathrm{O}$ at position $\mathrm{T} 21$ in the western part and $\mathrm{T} 47$ in the eastern part of the EGIG-line.

transport, a detailed comparison of ion concentrations in the parallel cores at positions T99 and T43 recovered during the consecutive field seasons 1990/1992 was performed. To do so, sample distributions of the logarithmic ion concentrations in the 1990 cores at T99 and T43 were compared with their unaffected counterparts of 1992 . This revealed a significant mode of up to a factor of two elevated ion concentrations in the frequency distributions for $\mathrm{Cl}^{-}, \mathrm{Na}^{+}, \mathrm{SO}_{4}^{2-}$ and $\mathrm{K}^{+}$(not presented here) but not for $\mathrm{NO}_{3}^{-}, \mathrm{Ca}^{2+}$ and $\mathrm{NH}_{4}^{+}$, $\mathrm{Mg}^{2+}$ (not presented here). The lack of dust contamination $\left(\mathrm{Ca}^{2+}, \mathrm{Mg}^{2+}\right)$ as well as lack of a $\mathrm{NO}_{3}^{-}$surplus supports sufficient clean field processing with respect to these species. In the case of $\mathrm{NH}_{4}^{+}$, absence of extra contamination modes points to minor exchange of melt water during transport with its ambient air containing relatively large amounts of $\mathrm{NH}_{3}$. However, the occurrence of excess concentration modes in $\mathrm{Cl}^{-}, \mathrm{Na}^{+}, \mathrm{K}^{+}$and possibly $\mathrm{SO}_{4}^{2-}$ points to slight exchange of sample water with the melt water found in the uncleaned storage bags through microcracks in the folds and welds of the PE sample bags. Concentrations of the affected samples (their number $<30 \%$ of all samples in individual cores) were excluded in the 1990 firn cores from further analysis. Following annual water weighted concentration means were calculated according to the $\delta^{18} \mathrm{O}$ - or $\mathrm{H}_{2} \mathrm{O}_{2}$ profile. Due to the data reduction performed on the records along EGIG-west, some individual years suffered from significant gaps in the profile. Such years are not believed to represent one year's concentration average, thus, were 
excluded from the annual mean data set. Additionally, for comparison, years previous to 1982 were not taken into account to ensure compatibility of the time span covered by each core.

Both $T$-test and parameter-free Wilcoxon-test performed on the thus reduced annual water weighted means showed no significant difference $(p=5 \%)$ between the cores drilled in 1990 and 1992 at positions T99 and T43. The reduced data set, therefore, is regarded as reliable. This is also corroborated by the distinct seasonal pattern revealed from the 1990 cores which is virtually the same as observed at other sites in central Greenland (see the following section).

\section{RESULTS AND DISCUSSION}

\section{Temporal variations}

Seasonal input pattern: Detailed reconstruction of the seasonal variation of chemical firn concentrations is highly dependent on the resolution achieved since

- atmospheric concentrations of aerosol species are subject to high variability on a daily and seasonal scale due to their relatively low atmospheric lifetimes;

- snow concentrations of mainly wet deposited species are coupled to the atmosphere by single precipitation events;

- efficiencies of wet deposition processes are dependent on meteorological parameters such as temperature (Davidson, 1989); and

- snow chemistry strata are subject to various postdepositional changes (sublimation, diffusion, wind drift, etc.) (Bales and Wolff, 1995).

Due to the constraints introduced by the low drill diameter of our cores $(2 \mathrm{in}$.) and by minimum sample volume mandatory for analyses only at the high accumulation sites T05, T09, T13, T17, T21 in the west and all the firn cores drilled during EGIG-east (sample resolution $\sim 6-8$ samples/a) seasonal variations in firn concentrations could be reasonably investigated. For these cores, annual concentration maxima were identified and their phase shift relative to the $\delta^{18} \mathrm{O}$ - or $\mathrm{H}_{2} \mathrm{O}_{2}$-profile determined (to illustrate the seasonal pattern, ionic profiles of two representative firn cores drilled in the western (T21) and in the eastern part (T47) of the EGIG-line are plotted in Fig. 3).

Despite the resolution constraints, each component shows a distinct seasonal variation. Furthermore, within the limits set by the temporal resolution achieved, no geographical variation in peak timing can be detected along the EGIG-line.

Sulphate, mainly photochemically produced from its reactive gaseous precursor $\mathrm{SO}_{2}$, which nowadays is governed by anthropogenic emissions, is high in winter/spring. During that season transport of industrial $\mathrm{SO}_{2}$-emissions from middle latitudes to the Arctic is efficient due to the southward shift of the polar front (Heidam, 1984). Additionally, increased $\mathrm{OH}$ concentrations at polar sunrise result in higher $\mathrm{SO}_{2}$ oxidation rates, thus higher atmospheric sulphate concentrations. Occasionally occurring summer peaks in sulphate firn concentrations may partly be attributed to higher biogenic sulphur emissions during that season ( $\mathrm{Li}$ and Barrie, 1993; Li et al., 1993).

Calcium - here regarded as tracer for continentally derived mineral dust aerosol - shows well-defined concentration maxima in spring. Large parts of the continental mineral dust source areas are enclosed by the polar front during the winter half-year resulting in an efficient transport of mineral dust aerosol to higher latitudes. The well-defined calcium peak is attributed to additionally enhanced source strength in spring due to the retreating snow cover in middle latitudes during that time of the year (Steffensen, 1988).

Nitrate firn concentrations reach their maximum in summer and are lower during winter; the relative concentration amplitude, however, is smaller than that for the other species investigated. Nitrate, mainly derived from anthropogenical $\mathrm{NO}_{x}$ emissions from middle latitudes, follows the same long-range transport pathway as $\mathrm{SO}_{2}$. However, non-photochemical $\mathrm{NO}_{x}$-oxidation (Tuazon et al., 1983) during the polar night prevents the arctic reservoir from filling up in the same way as in the case of $\mathrm{SO}_{2}$. The nitrate summer maximum in snow is not yet satisfactorily explained. Davidson et al. (1989) proposed enhanced scavenging of atmospheric nitrate loadings in summer due to higher atmospheric temperatures (higher probability for the occurence of riming). On the other hand, photochemical decomposition during summer of peroxyacetyl nitrate (PAN) (Laj et al., 1992), acting as transient reservoir for reactive nitrogen, or stratospheric inputs in early summer may be responsible for higher atmospheric nitrate concentrations.

Sodium as well as chloride regularily show maxima in winter/spring; occasionally, secondary sea-salt peaks occur during summer. Increased sea-salt deposits in the winter half-year are attributed to enhanced cyclonic activity (Liljequist, 1970) over the Northern Atlantic and the Baffin Bay, leading to higher sea-spray production; thus, higher sea salt fluxes into the atmosphere by wind dispersion. The origin of the $\mathrm{Clx}^{-}$, contributing up to $50 \%$ of chloride concentrations in summer needs further investigation. Outcome of principle component analysis performed on the data set of each core yields a common factor consisting of $\mathrm{Clx}^{-}$and $\mathrm{NO}_{3}^{-}$with relatively high factor loadings $(\sim 0.7)$ of both components (Fischer, 1993). Thus, an $\mathrm{NO}_{3}^{-}$coupled origin of $\mathrm{Clx}^{-}$seems to be likely. Release of $\mathrm{HCl}$ from sea-salt aerosol reacting with high atmospheric nitric acid concentrations in summer would possibly explain increased $\mathrm{Clx}^{-}$values distant to the coast due to the higher atmospheric lifetime of gaseous $\mathrm{HCl}$ compared to the relatively large sea-salt particles.

Peak timing in our study agrees well with other findings from south Greenland (Mayewski et al., 1987; Davidson et al., 1989; Beer et al., 1991) and own findings (unpublished data) from northeast Greenland. Since all these sites cover a wide range of 
geographical and climatological conditions of the Greenland Ice Sheet, we assume a common temporal deposition pattern for each species over the entire ice sheet.

Interannual variability: For each position average snow accumulation rates $\bar{A}$, average annual water weighted concentration means $\bar{C}$ (see Table 1) and average annual deposition rates $\bar{J}$ together with their standard deviations $\sigma$ were determined according to

$$
\begin{array}{cc}
\bar{A}=\frac{1}{n} \sum_{i=1}^{n} A_{i}, & \sigma_{A}=\frac{1}{n-1} \sqrt{\sum_{i=1}^{n}\left(A_{i}-\bar{A}\right)} \\
\bar{C}=\frac{1}{n} \sum_{i=1}^{n} C_{i}, & \sigma_{C}=\frac{1}{n-1} \sqrt{\sum_{i=1}^{n}\left(C_{i}-\bar{C}\right)^{2}} \\
\bar{J}=\frac{1}{n} \sum_{i=1}^{n} C_{i} A_{i}, & \sigma_{J}=\frac{1}{n-1} \sqrt{\sum_{i=1}^{n}\left(C_{i} A_{i}-\bar{J}\right)^{2}} .
\end{array}
$$

$\left(C_{i}\right.$ is the annual water weighted concentration of year $i, A_{i}$ the corresponding annual snow accumulation and $n$ the number of years covered by the firn core). The limits of each one-year interval were defined by the summer maxima in the $\delta^{18} \mathrm{O}$ - and $\mathrm{H}_{2} \mathrm{O}_{2}$-profile, respectively. By means of averaging single years, instead of whole cores, it is possible to calculate the temporal representative variability measure $\sigma$ and to exclude specific years in the cores along EGIG-west suffering from significant gaps in the ion profiles due to missing (i.e. contaminated) data.

The annual snow accumulation $A_{i}$ at each position exhibits a relatively low natural variability from year to year with $\sigma_{A} / \bar{A}$ for each core ranging between 15 and $25 \%$ approximately. Extreme deviations of $A_{i}$ from their average $\bar{A}$ appear to be a large-scale phenomenon (Anklin et al., 1994; Fischer et al., 1995), with individual years of extraordinarily higher/lower $A_{i}$ consistently found in all cores along the EGIG-line.
As expected, annual ion concentration means are characterised by significantly higher scatter than the accumulation rates with $\sigma_{C} / \bar{C}$ in individual cores ranging from approximately 15 to $30 \%$ for nitrate and sulphate to 20 to $60 \%$ for sea-salt and mineral-dust components. Only slight indications for geographically consistent interannual variations for nitrate and sulphate (as clearly observed for $A_{i}$ ) may be revealed from the annual firn concentrations.

\section{Spatial variations}

Geographical distribution: The geographical distribution of average annual water weighted concentrations $\bar{C}$, displayed in Fig. 4, shows increasing nitrate, sulphate as well as calcium concentrations (the latter with significantly higher scatter) from west to east. Chloride and sodium, however, decrease from the western-most position T05 to T31. The eastern part of the transect shows uniform but, compared to T31, higher sea-salt concentrations in the snow pack, which slightly increase at the eastern-most positions. Note that positions T43, NST08 and T99 in Fig. 4 are all situated on the ice divide, however, T99 lies $\sim 150 \mathrm{~km}$ north of T43.

Changing atmospheric circulation patterns in the course of the year and/or higher temperatures during summer, possibly associated with higher scavenging ratios, may affect the geographical distribution of ionic species in the firn. To assess such effects, average concentrations for the winter and summer half-years were calculated separately (the limits of individual half-years defined by the mean value between adjacent summer maxima and winter minima in the $\delta^{18} \mathrm{O}$ $\left(\mathrm{H}_{2} \mathrm{O}_{2}\right)$-profile). As expected, this procedure leads to generally higher winter and lower summer levels for sulphate and vice versa for nitrate at each position (see the section on seasonal variations). However, the increasing trend from west to east in the overall

Table 1. Average annual water weighted firn concentrations $\bar{C}$ in $\mathrm{ng} \mathrm{g}^{-1}$ and average annual accumulation $\bar{A}$ in $\mathrm{cm}$ water

\begin{tabular}{|c|c|c|c|c|c|c|c|c|c|}
\hline Position & Latitude & Longitude & $\mathrm{NO}_{3}^{-}$ & $\mathrm{SO}_{4}^{2-}$ & $\mathrm{Cl}^{-}$ & $\mathrm{Na}^{+}$ & $\mathrm{Ca}^{2+}$ & $A$ & $n$ \\
\hline T05 & $69^{\circ} 51^{\prime} \mathrm{N}$ & $47^{\prime} 15^{\prime} \mathrm{W}$ & $118 \pm 19$ & $94 \pm 15$ & $34 \pm 8$ & $17 \pm 2$ & $9 \pm 2$ & $46 \pm 10$ & 5 \\
\hline T09 & $70^{\circ} 00^{\prime} \mathrm{N}$ & $46^{\prime} 18^{\prime} \mathrm{W}$ & $134 \pm 26$ & $105 \pm 19$ & $33 \pm 8$ & $12 \pm 5$ & $7 \pm 3$ & $41 \pm 9$ & 9 \\
\hline T13 & $70^{\prime} 14^{\prime} \mathrm{N}$ & $45^{\circ} 01^{\prime} \mathrm{W}$ & $107 \pm 18$ & $73 \pm 19$ & $24 \pm 9$ & $13 \pm 3$ & $9 \pm 4$ & $46 \pm 9$ & 8 \\
\hline T17 & $7022^{\prime} \mathrm{N}$ & $44^{\prime} 06^{\prime} \mathrm{W}$ & $117 \pm 16$ & $83 \pm 13$ & $20 \pm 6$ & $13 \pm 5$ & $11 \pm 3$ & $44 \pm 8$ & 9 \\
\hline T21 & $7033^{\prime} \mathrm{N}$ & $43^{\circ} 01^{\prime} \mathrm{N}$ & $112 \pm 14$ & $75 \pm 13$ & $21 \pm 2$ & $7 \pm 1$ & $4 \pm 2$ & $44 \pm 9$ & 9 \\
\hline T27 & $70^{\prime} 46^{\prime} \mathrm{N}$ & $41^{\circ} 33^{\prime} \mathrm{N}$ & $113 \pm 32$ & $78 \pm 12$ & $19 \pm 1$ & $11 \pm 6$ & $9 \pm 2$ & $39 \pm 7$ & 9 \\
\hline T31 & $70^{\prime} 55^{\prime} \mathrm{N}$ & $40^{\circ} 38^{\prime} \mathrm{W}$ & $133 \pm 30$ & $88 \pm 17$ & $18 \pm 4$ & $10 \pm 6$ & $9 \pm 2$ & $34 \pm 6$ & 10 \\
\hline T41 & $71^{\circ} 05^{\prime} \mathrm{N}$ & $37^{\prime} 55^{\prime} \mathrm{W}$ & $144 \pm 23$ & $95 \pm 16$ & $30 \pm 10$ & $17 \pm 7$ & $13 \pm 5$ & $25 \pm 4$ & 12 \\
\hline T43'90 & $7107^{\prime} \mathrm{N}$ & $37^{\prime} 19^{\prime} \mathrm{W}$ & $146 \pm 23$ & $93 \pm 16$ & $29 \pm 9$ & $14 \pm 4$ & $15 \pm 7$ & $23 \pm 4$ & 14 \\
\hline T99'90 & $7235^{\prime} \mathrm{N}$ & $37^{\circ} 38^{\prime} \mathrm{W}$ & $142 \pm 29$ & $119 \pm 19$ & $28 \pm 7$ & $17 \pm 6$ & $11 \pm 3$ & $20 \pm 4$ & 21 \\
\hline Т99'92 & $7235^{\prime} \mathrm{N}$ & $37^{\circ} 38^{\prime} \mathrm{N}$ & $138 \pm 15$ & $92 \pm 21$ & $28 \pm 4$ & $12 \pm 3$ & $15 \pm 8$ & $19 \pm 5$ & 9 \\
\hline NST08 & $7152^{\prime} \mathrm{N}$ & $37^{\circ} 46^{\prime} \mathrm{N}$ & $153 \pm 25$ & $107 \pm 29$ & $25 \pm 9$ & $9 \pm 5$ & $10 \pm 6$ & $23 \pm 3$ & 5 \\
\hline T43'92 & $71^{\circ} 07^{\prime} \mathrm{N}$ & $37^{\prime} 19^{\prime} \mathrm{W}$ & $144 \pm 13$ & $82 \pm 15$ & $26 \pm 4$ & $11 \pm 5$ & $14 \pm 4$ & $25 \pm 4$ & 8 \\
\hline T47 & $71^{\prime} 12^{\prime} \mathrm{N}$ & $35^{\prime} 57^{\prime} \mathrm{W}$ & $143 \pm 25$ & $90 \pm 21$ & $26 \pm 8$ & $12+5$ & $14 \pm 7$ & $22 \pm 4$ & 8 \\
\hline T53 & $71^{\prime} 21^{\prime} \mathrm{N}$ & $32^{\prime} 28^{\prime} \mathrm{W}$ & $134 \pm 30$ & $104 \pm 26$ & $27 \pm 10$ & $12 \pm 6$ & $14 \pm 5$ & $23 \pm 5$ & 9 \\
\hline T61 & $7213^{\prime} \mathrm{N}$ & $3219^{\prime} \mathrm{W}$ & $144 \pm 38$ & $106 \pm 37$ & $27 \pm 7$ & $14 \pm 8$ & $9 \pm 4$ & $19 \pm 5$ & 8 \\
\hline T66 & $7229^{\prime} \mathrm{N}$ & $30^{\circ} 46^{\prime} \mathrm{W}$ & $159 \pm 50$ & $111 \pm 29$ & $32 \pm 10$ & $16 \pm 8$ & $10 \pm 6$ & $17 \pm 4$ & 6 \\
\hline
\end{tabular}
equivalent per year together with their standard deviations at all drill sites along the EGIG-line (the coordinates of the drill sites and the time spans covered by individual cores are also listed) 


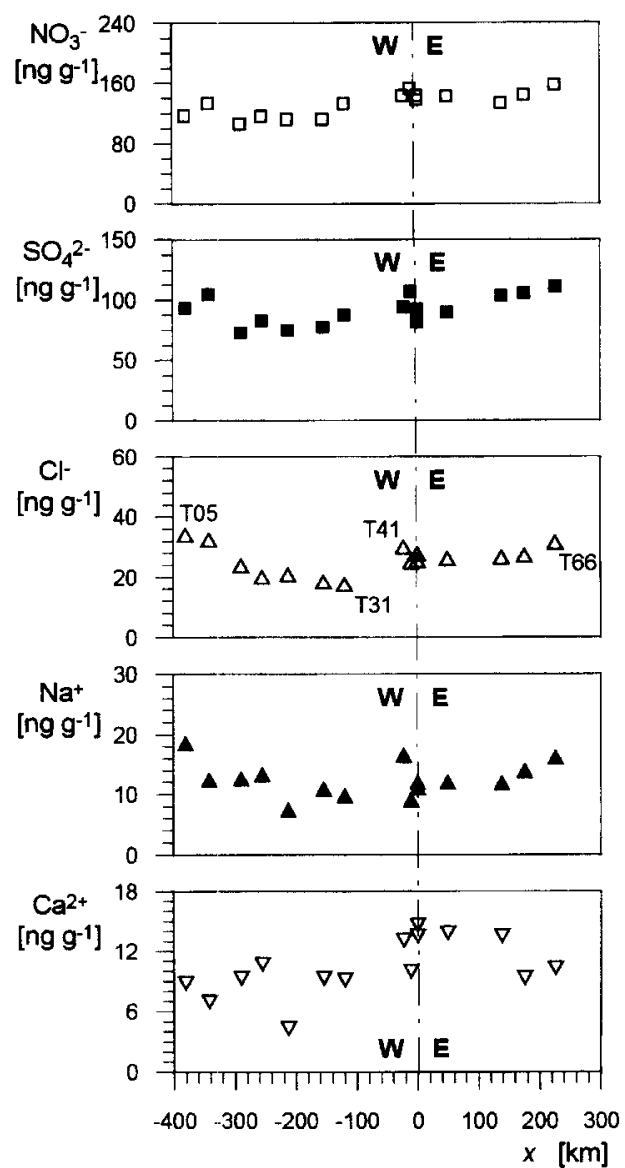

Fig. 4. Geographical distribution of firn concentrations of the ionic components investigated along the EGIG-line. Plotted are average annual water weighted concentrations in $\mathrm{ng} \mathrm{g}^{\prime 1}$ vs distance to the ice divide in $\mathrm{km}$ taken positive in easterly direction.

geographical distribution remains virtually unchanged. This strongly limits the importance of seasonally varying temperatures and possible seasonal circulation changes on nitrate and sulphate concentrations on a multiyear time scale along the EGIGline. Ion concentrations in single precipitation events, however, may still be subject to significant variability.

According to the seasonal variation described before, winter concentrations for the sea-salt components were higher than the average annual mean and showed a strong decreasing trend from T05 to T31. Summer concentrations, however, did not reveal such a strong trend. We attribute this difference to the higher cyclonic influence, as significant factor for seasalt concentrations in central Greenland firn, during the winter half-year.

As displayed in Fig. 2, mean snow accumulation rates exhibit a systematic overall decrease by up to a factor of three going from west to east. Thus the mean deposition fluxes $\bar{J}$ of nitrate, sulphate and calcium depositions, plotted in Fig. 5, also show a decreasing trend towards lower longitudes along the

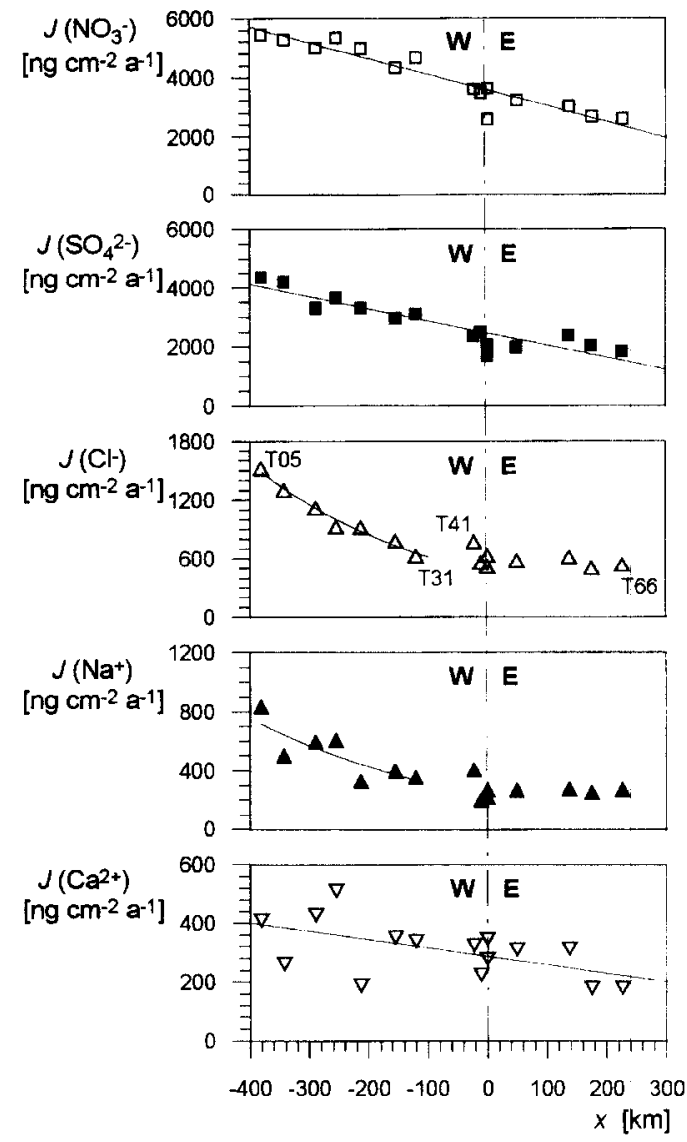

Fig. 5. Geographical distribution of deposition fluxes of the ionic components investigated along the EGIG-line. Plotted are average annual deposition rates in $\mathrm{ng} \mathrm{cm}^{-2} \mathrm{a}^{-1}$ vs distance to the ice divide in $\mathrm{km}$ together with their linear regression fit.

EGIG-line, which may be parametrised by the following linear relationships:

$$
\begin{gathered}
J\left(\mathrm{NO}_{3}^{-}\right)=(-540 \pm 50) x+(3565 \pm 100) \\
{\left[\mathrm{ng} \mathrm{cm}^{-2} \mathrm{a}^{-1}\right], \quad r^{2}=0.90} \\
J\left(\mathrm{SO}_{4}^{2-}\right)=(-410 \pm 50) x+(2468 \pm 101) \\
{\left[\mathrm{ng} \mathrm{cm}^{-2} \mathrm{a}^{-1}\right], \quad r^{2}=0.84} \\
J\left(\mathrm{Ca}^{2+}\right)=(-30 \pm 10) x+(287 \pm 23) \\
{\left[\mathrm{ng} \mathrm{cm}^{-2} \mathrm{a}^{-1}\right],}
\end{gathered}
$$

with $x$ (in units of $100 \mathrm{~km}$ ) being the distance to the ice divide taken positive in easterly direction. (Values given in parentheses are regression parameters together with their standard errors.)

For sea-salt species (already showing a prominent decline along EGIG-west in ion concentrations) deposition fluxes in Fig. 5 appear to decrease exponentially from the west to the ice divide. This geographical distribution, again, supports cyclonic influence, 
entering central Greenland mainly from the west, to be responsible for the transport of major parts of the sea-salt load onto the central Greenland Ice Sheet.

In the case of chloride, linear regression of the logarithmic deposition rates from T05 to T31 leads to

$$
\begin{gathered}
J\left(\mathrm{Cl}^{-}\right)=\exp ((-0.31 \pm 0.02) x+(6.11 \pm 0.06)) \\
{\left[\mathrm{ng} \mathrm{cm}^{-2} \mathrm{a}^{-1}\right] ; \quad r^{2}=0.97}
\end{gathered}
$$

corresponding to a scale length of $320 \mathrm{~km}$. Equivalent evaluation of sea-salt flux profiles along an $\sim 600 \mathrm{~km}$ inland traverse on the Filchner-Ronne Shelf Ice, Antarctica, by Minikin et al. (1994) lead to a scale length of $\sim 150 \mathrm{~km}$, i.e. only half the value obtained for the EGIG-line. Because of the proximity to open water and the lack of orographic changes, the particle size distribution of the aerosol encountered over the ice shelf is shifted to larger aerosols as compared to the sea-salt aerosol found over the EGIG-line. The latter is already aged when approaching the interior of the Greenland Ice Sheet as corroborated by its total sea salt concentration which is more than one order of magnitude lower than that on the shelf ice. Thus, higher gradients in sea-salt fluxes on the ice shelf are associated with significant depletion of the fraction of larger sea-salt particles with lower atmospheric lifetimes.

The geographical deposition patterns along the EGIG-line are also illustrated by calculating temporal representative regional mean deposition rates by averaging equations (1)-(4). Values for the areas east and west of the ice divide are listed in Table 2 together with the average over the entire EGIG-Line. Here average sea-salt depositions in the west are nearly twice as high as in the eastern part of the EGIG-line. Nitrate and sulphate depositions in the east reach approximately $65 \%$, and calcium depositions $75 \%$ of the value in the west.

Accumulation rate dependence. In a formal sense, the total deposition fluxes $J_{\mathbf{t}}$ (as determined above) may be separated into three essential terms.

$$
J_{\mathrm{t}}=J_{\mathrm{w}}+J_{\mathrm{d}}+\Delta J_{\mathrm{d}}
$$

with $J_{\mathrm{w}}, J_{\mathrm{d}}$ denoting the common wet and dry deposition fluxes, respectively. Here $\Delta J_{\mathrm{d}}$ comprehends a series of supplementary depositional (and evasional) processes not directly associated with precipitationforming events, as for example firn ventilation (Harder et al., 1991), scavenging by or evaporation from drifting ice crystals (Pomeroy et al., 1991), surface rime or frost deposition (Bergin et al., 1995) and reevaporation from surface snow (Wolff, 1995). If irreversibly deposited species like sulphate are considered, reevaporation effects may be neglected and, furthermore, for the sake of simplicity the net snow accumulation rate $A$ is set equal to the precipitation rate implying that frost or surface rime accumulation $\Delta A$ is balanced by water vapour sublimation. Under these assumptions, the locally representative mean
Table 2. Recent regional mean annual deposition rates in $\mathrm{ng} \mathrm{cm}-2 \mathrm{a}^{-1}$ along the EGIG-line west and east of the ice divide and for comparison along the whole EGIG-line

\begin{tabular}{lccrcc}
\hline Flux & $\mathrm{NO}_{3}^{-}$ & $\mathrm{SO}_{4}^{2-}$ & \multicolumn{1}{c}{$\mathrm{Cl}^{-}$} & $\mathrm{Na}^{+}$ & $\mathrm{Ca}^{2+}$ \\
\hline$J_{\text {west }}$ & 4918 & 3495 & 1006 & 508 & 362 \\
$J_{\text {east }}$ & 3278 & 2250 & 591 & 272 & 271 \\
$J_{\text {total }}$ & 3982 & 2785 & 769 & 373 & 310 \\
\hline
\end{tabular}

firn concentration (averaged over an appropriate number of annual cycles) becomes $C_{\mathrm{f}}=J_{\mathrm{t}} A^{-1}$ and using equation (5)

$$
C_{\mathrm{f}}=C_{\mathrm{p}}+\frac{C_{\mathrm{a}} v_{\mathrm{d}}}{A}+C_{\mathrm{r}} \frac{\Delta A}{A}
$$

with $C_{\mathrm{p}}$ being the precipitation impurity concentration mainly dependend on the atmospheric load $C_{a}$ and the incloud scavenging efficiency, $v_{\mathrm{d}}$ the dry deposition velocity possibly enhanced by firn ventilation and drifting snow scavenging and $C_{\mathrm{r}}$ the impurity concentration in surface rime or frost. Despite surface rime accumulation rates $\Delta A$ may only contribute a few per cent to the overall snow deposition $A$, the last term on the right-hand side of equation (6) may substantially increase the mean firn concentration of submicron aerosol. For example, in surface rime deposited at Summit (T99) $\mathrm{NH}_{4}^{+}$and $\mathrm{SO}_{4}^{2-}$ concentrations are found to be enhanced over the typical fresh snow values by roughly a factor of 7 and 5, respectively (Bergin et al., 1995). Similar enrichments are observed in cloud water with respect to (unrimed) falling snow at high elevation Alpine sites during the winter season (Brantner et al., 1994).

Referring to the EGIG-line the mean snow accumulation rate $A$ appears to be the only parameter in equation (6) which is subject to substantial spatial change. If this assumption holds, a linear relationship between $C_{\mathrm{f}}$ and $A^{-1}$ is expected. Therefore, average annual water weighted firn concentrations for nitrate, sulphate, chloride and calcium are plotted vs inverse snow accumulation rate in Fig. 6. Nitrate, sulphate and with higher scatter also calcium, indeed, are linearly coupled to inverse accumulation rates along the whole EGIG-line. According to equation (6), this points to a spatially uniform total dry deposition flux and to an uniform distribution of the respective fresh snow concentration $C_{\mathrm{p}}$ over the investigated area. Provided a more or less constant scavenging efficiency holds true, this would indicate only minor spatial changes of the near-surface atmospheric load $C_{a}$ over the EGIG-line. The similar overall response of the mean sulphate and nitrate concentrations on increasing snow accumulation (leading to a dilution of the total dry deposited fraction), however, is unexpected in view of the predominance of gas phase vs particulate nitrate over Greenland. As shown by Silvente 

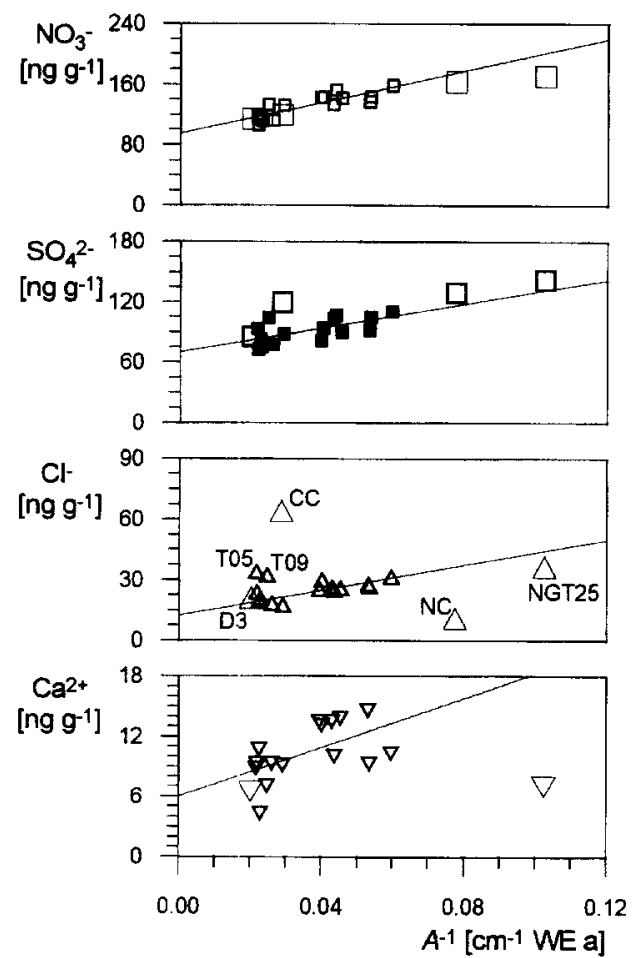

Fig. 6. Average annual water weighted firn concentration of $\mathrm{NO}_{3}^{-}, \mathrm{SO}_{4}^{2-}, \mathrm{Cl}^{-}$and $\mathrm{Ca}^{2+}$ in $\mathrm{ng} \mathrm{cm}^{-2} \mathrm{a}^{-1}$ as a function of inverse average accumulation rate in $(\mathrm{cm}$ water equivalent per year) ${ }^{-1}$ along the EGIG-line (small symbols) together with their linear regression fit. Also included are values for Dye3 (D3), North Central (NC), Camp Century (CC) taken from Herron (1982) and our own unpublished results from NGT25 (large symbols)

and Legrand (1995) for the Summit summer season, nitric acid is scavenged very efficiently in growing ice crystals leading to an extremly high air/snow scavenging ratio in the order of 10,000 . This, as well as any possible $\mathrm{HNO}_{3}$-remobilisation from the snow surface (Wolff, 1995), would make the portion of dry deposited nitrate relatively unimportant, especially when compared to the situation of sulphate. Thus, the reason for the substantial contribution of total dry deposited nitrate derived here, accounting for up to $40 \%$ in low accumulation areas along the EGIGline, needs further investigation. A possible explanation may be a significant formation of surface frost (co-condensation of water vapour and nitric acid). Also a systematic depletion of atmospheric nitrate loading with increasing mean precipitation rates due to the high scavenging efficiency may obliterate the picture.

The slope and intercept in Fig. 6 indicate the total dry deposition flux (reflecting all contributions from non-precipitating events) and the mean fresh snow concentration, respectively. Note that the same parameters can be derived by linear regression of $J_{\mathrm{t}}$ vs $A$ along the EGIG-line (however, an in- creasing trend of $J_{1}$ is anticipated here in any case), leading to

$$
\begin{aligned}
& J\left(\mathrm{NO}_{3}^{-}\right)=(93.7 \pm 6.4) A+(1080 \pm 211) \\
& {\left[\mathrm{ng} \mathrm{cm}^{-2} \mathrm{a}^{-1}\right], \quad r^{2}=0.94} \\
& J\left(\mathrm{SO}_{4}^{2-}\right)=(70.4 \pm 8.7) A+(610 \pm 285) \\
& \text { [ng cm } \mathrm{ng}^{-2} \mathrm{a}^{-1} \text { ] }, \quad r^{2}=0.84 \\
& J\left(\mathrm{Ca}^{2+}\right)=(5.0 \pm 2.0) A+(156 \pm 64) \\
& {\left[\mathrm{ng} \mathrm{cm} \mathrm{cm}^{-2} \mathrm{a}^{-1}\right], \quad r^{2}=0.33 \text {. }}
\end{aligned}
$$

with $A$ in units of $\mathrm{cm} \mathrm{WE} \mathrm{\textrm {a } ^ { - 1 }}$

As noted before, sea-salt components do not show such a uniform behaviour over the whole area investigated, since marine-influenced sites near the west coast (T05, T09) dominate the picture in Fig. 6. In the area between $\mathrm{T} 17$ and $\mathrm{T} 66$, i.e. appropriately distant to marine source regions, sea-salt concentrations in the firn appear to be governed by the accumulation rate as well with

$$
\begin{gathered}
J\left(\mathrm{Cl}^{-}\right)=(13.7 \pm 2.1) A+(284 \pm 61) \\
{\left[\mathrm{ng} \mathrm{cm}-2 \mathrm{a}^{-1}\right] ; \quad r^{2}=0.82}
\end{gathered}
$$

According to equation (6), the intercepts in equations (7)-(10) may be interpreted as average total dry deposition fluxes. The relative fractions of the total dry deposition to the overall inputs of sulphate, nitrate, calcium and chloride for the average accumulation rate at Summit, for example, are 37, 30, 61 and $51 \%$, respectively. These numbers are in close agreement with direct observations made by Bergin et $a$. (1995) during the summer season at this site (except for nitrate for which no gas phase dry deposition flux was reported). This strongly suggests our approach to be an alternative way to determine average dry deposition rates, adding significant temporal representativeness. Furthermore, the value for calcium is in good agreement with $J_{\mathrm{d}}=160 \mathrm{ngcm}^{-2} \mathrm{a}^{-1}$ derived by Davidson et al. (1981) for Dye3, determined by parallel aerosol and fresh snow sampling. This indicates that total dry deposition of mineral dust aerosol in south and central Greenland are of comparable magnitude. Another illustrative parameter representative for the depositional regime on the Greenland Ice Sheet is the critical accumulation rate, where wet deposition equals total dry deposition. This parameter may also be derived from equations (7)-(10) leading to $11.5,8.7,31.2$ and $20.7 \mathrm{~cm} \mathrm{WE} \mathrm{a}^{1}$ for nitrate, sulphate, calcium and chloride, respectively. These numbers imply that total calcium (and with restrictions also chloride) deposition is governed by dry deposition over major parts of the EGIG-line. while for nitrate and sulphate total dry deposition is only dominant at low accumulation sites as, for example, encountered in vast areas of northeast Greenland (Friedmann et al., 1995).

Also included in Fig. 6 are average firn concentrations of the ionic species investigated at Dye? 
(D3), North Central (NC) and Camp Century (CC) compiled by Herron (1982) for the time span 1973-1981 and own unpublished data from a snow pit at NGT25 in northeast Greenland $79^{\circ} 14^{\prime} \mathrm{N}$, $37^{\circ} 57^{\prime} \mathrm{W}$, which very well fit into the linear relations for nitrate and sulphate along the EGIG-line.

Although the sites mentioned above are situated in quite different geographical regimes of the Greenland Ice Sheet, deposition rates obviously show a uniform accumulation dependence. Thus, based on the data presently available we propose a uniform relation for these components over the entire Ice Sheet. Nitrate concentration at the low accumulation site NGT25 seems to deviate slightly from this picture, possibly due to postdepositional $\mathrm{NO}_{3}^{-}$loss from aging surface strata which are exposed to the atmosphere for a long time without significant fresh snow cover to suppress nitrate remobilisation. This assumption is also supported by a series of own pit studies from northeast Greenland (unpublished data), which occasionally show extraordinary high nitrate concentrations in the uppermost surface strata, attributed to fresh fallen snow, which was not yet subject to such postdepositional $\mathrm{NO}_{3}^{-}$loss. The picture for sea-salt aerosol does not show a uniform accumulation dependence, since geographical trends in atmospheric aerosol concentrations exert strong influence on sea-salt deposition. Especially CC, situated close to local marine source areas, shows exceedingly high $\mathrm{Cl}^{-}$depositions despite low accumulation rate. Average $\mathrm{Ca}^{2+}$ firn concentration for NGT25 is very low, possibly, because of significantly lower atmospheric calcium concentrations in northeast Greenland. The strict linear dependence of nitrate and sulphate firn concentrations on accumulation rates in Fig. 6 also suggests that spatial variations in atmospheric concentrations of these components are small over the Greenland Ice Sheet in comparison with the wide range of snow accumulation rates covered by this study.

\section{CONCLUSIONS}

Seasonal and geographical variations of sea-salt and mineral dust components as well as of nitrate and sulphate in recent central Greenland firn were investigated along an east-west transect through central Greenland.

Concentration profiles of each component showed essentially the same seasonal variations at all positions along the EGIG-line, also in agreement with other drill sites on the Greenland Ice Sheet. This suggests spatially uniform seasonal input patterns for all high altitude sites, thus chemical firn parameters appear to be influenced by an aerosol body reflecting the same sources and circulation systems over the entire Greenland dry snow zone.

Since all the drill sites cover a wide range of geographical and climatological conditions, this uniformity also implies that local conditions appear not to be the primary factor controlling the seasonal input function of aerosols and reactive trace gases into Greenland firn.

The geographical distributions of average nitrate, sulphate and calcium concentrations in the firn show an increasing trend from west to east, which is of comparable magnitude during both winter and summer. Thus seasonal circulation changes on top of the ice sheet and seasonally varying temperatures are unlikely to be the controlling factors of nitrate and sulphate firn concentrations on a decadal scale.

Instead, average nitrate, sulphate and calcium firn concentrations appear to be primarily governed by the snow accumulation rate over the whole EGIGline. Since data from other drill sites all over the central Greenland Ice Sheet agree with this picture very well, a common linear relationship between accumulation and deposition of non sea salt components may be assumed for the entire Greenland dry snow zone.

Sea-salt deposition rates in the western-most parts of the EGIG-line show a strong decrease with distance to the west coast, exceeding the decrease solely produced by the concurrent decline in snow accumulation. Also indicated by the geographical distribution of stable water isotopes this distribution is most likely governed by cyclonic systems developing over the Northern Atlantic and entering Greenland from the west. Major parts of both sea-salt aerosol and precipitated water vapour transported onto the Greenland Ice Sheet may, thus, be attributed to these low pressure systems. In areas on the ice sheet distant to marine source regions sea-salt concentrations in the firn appear to be governed by local accumulation rates as well.

Linear regression of average impurity deposition fluxes and snow accumulation rates allows to assess the (total) dry deposited aerosol fraction to the overall impurity input and to infer the critical accumulation rate on the central Greenland Ice Sheet, where dry deposition starts to dominate over wet deposition. Thus, a temporally representative average total dry deposition flux of 1080,610 and $156 \mathrm{ng} \mathrm{cm}^{-2} \mathrm{a}^{-1}$, corresponding to a critical accumulation rate of 11.5 , 8.7 , and $31.2 \mathrm{~cm} \mathrm{WE} \mathrm{a}^{-1}$ for nitrate, sulphate and calcium, respectively, could be derived.

The accumulation dependency of chemical firn parameters is especially relevant for the interpretation and comparison of deep ice core records. Significant temporal changes in snow accumulation during glacial/interglacial changes (Alley et al., 1993) will also lead to variations in aerosol firn concentrations (O'Brien et al., 1995) not necessarily accompanied by concurrent atmospheric concentration changes. Furthermore, the areas east and west of the ice divide reveal different dependences of annual snow accumulation rates on geographically changing mean annual temperatures. Annual snow accumulations along the EGIG-line west of the ice divide show a linear decrease with lower temperatures, while accumulation 
further east remains essentially constant despite increasing temperatures (Fischer et al., 1995). Thus accumulation rate and, hence, firn concentration records derived from ice cores retrieved from the western part of the central Greenland Ice Sheet will react more sensitively on changes in temperature than their counterparts in the east. Disentangling such glaciometeorological effects from atmospheric effects will be crucial for all conclusions drawn from deep ice core studies. This effort strongly relies on a well-known classification of the drill sites with respect to the overall glaciological and meteorological system prevailing on the ice sheet.

Extension of this study along a south-north transect in the so-far scarcely investigated area of northern Greenland, as carried out in a cooperation of the Alfred-Wegener-Institut, Bremerhaven, and the Institut für Umweltphysik, Heidelberg, in the years 1993-1995, is expected to further improve our knowledge about seasonal and geographical deposition patterns governing the Greenland Ice Sheet.

Acknowledgements--Financial support for this study was provided by Deutsche Forschungsgemeinschaft (DFG) and covering the field activities in 1990 by Merck Stiftung and Freundeskreis der Heidelberger Akademie der Wissenschaften. We also want to acknowledge the Geodetic Institute of the University Braunschweig, and the GRIP GOC, which were in charge of the logistics. We would also like to thank K. Geis, M. Anklin and M. Laternser for their dedicated commitment to the glaciological field work during the traverses.

\section{REFERENCES}

Alley R.B., Meese D.A., Shuman C.A., Gow A.J., Taylor K.C.. Grootes P.M.. White J.W.C., Ram M., Waddington E.D., Mayewski P.A. and Zielinski G.A. (1993) Abrupt increase in Greenland snow accumulation at the end of the Younger Dryas event. Nature 362, 427-529.

Anklin M., Stauffer B., Geis K. and Wagenbach, D. (1994) Pattern of annual snow accumulation along a West Greenland flow line no significant change observed during recent decades. Tellus 46B, 294-303.

Bales R.C. and Wolff E.W. (1995) Interpreting natural climate signals in ice cores. EOS 76, 477, 482-483.

Beer J., Finkel R.C., Bonani G., Gäggeler H., Glach U., Jacob P., Klockow D., Langway C.C. Jr., Neftel A., Oeschger H., Schotterer U., Schwander J., Siegenthaler U., Suter M., Wagenbach D. and Wölfli W. (1991) Seasonal variations in the concentration of ${ }^{10} \mathrm{Be}, \mathrm{Cl}^{-}, \mathrm{NO}_{3}^{-}, \mathrm{SO}_{4}^{2-}$, $\mathrm{H}_{2} \mathrm{O}_{2},{ }^{210} \mathrm{~Pb},{ }^{3} \mathrm{H}$, mineral dust, and $\delta^{18} \mathrm{O}$ in Greenland snow. Atmospheric Environment 25A, 899--904.

Bergin M.H., Jaffrezo J.-L., Davidson C.I., Dibb J.E., Pandis S.N., Hillamo R., Maenhaut W., Kuhns H.D. and Makela T. (1995) The contribution of snow, fog, and dry depos. ition to the summer flux of anions and cations at Summit. Greenland. J. geophys. Res. 100, 16,275-16,288.

Boutron C. (1979) Trace element content of Greenland snows along an east--west transect. Geochim. Cosmochim. Acta 43, 1253-1258.

Brantner B., Fierlinger H., Berner A. and Puxbaum H. (1994) Cloudwater chemistry in the subcooled droplet regime at Mount Sonnblick (Austrian Alps). Wat. Air Soil Pollut. 74, 363-384.

Davidson C.I, Chu L., Grimm T.C., Nasta M.A. and Qamoos M.P. (1981) Wet and dry deposition of trace elements onto the Greenland Ice Sheet. Atmospheric Environment 15, 1429-1437.

Davidson C.I., Harrington J.R., Stephenson M.J., Small M.J., Boscoe F.P. and Gandley R.E. (1989) Seasonal variations in sulfate, nitrate and chloride in the Greenland Ice Sheet: relation to atmospheric concentrations. Atmospheric Environment 23, 2483-2493.

Fischer H. (1993) Räumliche und zeitliche Verteilung glaziometeorologischer, isotopischer und chemischer Firnparameter im Ausflueßgebiet Zentralgrölands. Diploma thesis, Institut für Umweltphysik. Universität Heidelberg. Germany

Fischer H., Wagenbach D., Laternser M. and Haeberli W. (1995) Glacio-meteorological and isotopic studies' along the EGIG line, central Greenland. J. Glaciol 41, 515 526 .

Friedmann A., Moore J.C., Thorsteinsson Th., Kipstuhl J. and Fischer H. (1995). A 1200 year record of accumulation from northern Greenland. Ann. Glaciol. 21, 1925.

Fuhrer K., Neftel A., Anklin A. and Maggi V. (1993) Continous measurements of hydrogen peroxide, formaldehyde calcium and ammonium concentrations along the new GRIP ice core from Summit. Central Greenland. Atmospheric Environment 27A, 1873-1880.

Hansson M.E. and Saltzmann E.S. (1993) The first Greenland ice core record of methanesulfonate and sulfate over a full glacial cycle. Geophys. Res. Lett. 20, 1163-1166.

Harder S.L., Grootes P.M. and Charlson R.J. (1991) Air snow exchange processes. Antarctic J. U.S. 26, 277.278.

Heidam N.Z. (1984) The components of the arctic aerosol. Atmospheric Environment 18, 329-343.

Herron M.M. (1982) Impurity sources of $\mathrm{F}^{-}, \mathrm{Cl}, \mathrm{NO}_{3}$ and $\mathrm{SO}_{4}^{2-}$ in Greenland and Antarctic precipitation. $J$. geophys. Res. 87, 3052--3060.

Laj P.. Palais J.M. and Sigurdsson H. (1992) Changing sources of impurities to the Greenland Ice Sheet over the last 250 years. Atmospheric Environment 14, 26272640.

Laternser M. (1994). Firn temperature measurements and snow pit studies on the EGIG eastern traverse of central Greenland, 1992. Open File Report. Arbeitsheft Nr. 15. VAW/ETH-Zurich.

Li S.-M. and Barrie L.A. (1993) Biogenic sulfur aerosol in the Arctic troposphere: 1. Contributions to total sulfate. $J$ geophys. Res. 98, 20,613-20,622.

Li S.-M., Barrie L.A. and Sirois A. (1993) Biogenic sulfur aerosol in the Arctic troposphere: 2. Trends and seasonal variations. $J$. geophys. Res. 98, 20,623 20,631

Liljequist G.H. (1970) Klimatologi. Generalstabens Litografiska Anstalt, Stockholm.

Mayewski P.A., Spencer M.J., Lyons Wm.B. and Twickler M.S. (1987) Seasonal and spatial trends in South Greenland snow chemistry. Atmospheric Entronment 21, $863-869$

Mayewski P.A., Spencer M.J., Twickler M.S. and Whitlow'S (1990) A glaciochemical survey of the summit region. Greenland. Ann. Glaciol. 14, 186-190.

Mayewski P.A., Lyons W.B., Spencer M.J.. Twickler M. Dansgaard W. Koci B., Davidson C.I. and Honrath R.E. (1986) Sulfate and nitrate concentrations from a South Greenland ice core. Science 232, 975977.

Minikin A., Wagenbach D., Graf W. and Kipfstuhl J.(1994) Spatial and seasonal variations of the snow chemistry at the central Filchner-Ronne Ice Shelf. Antarctica. Ann. Glaciol. 20, 283-290.

Neftel A., Beer J., Oeschger H., Zuercher F. and Finkel R.C. (1985) Sulphate and nitrate concentrations in snow from South Greenland. Nature 314, 611613.

O'Brien S.R., Mayewski P.A., Mceker L.D.. Meese D.A., Twickler M.S and Whitlow S.I. (1995) Complexity of Holocene climate as reconstructed from a Greenland ice core. Science 270, pp. 1962-1964.

Osada K. and Langway C.C. Jr. (1993) Background levels of formate and other ions in ice cores from inland Greenland. Geophys. Res. Lett. 20, 2647-2650. 
Pomeroy J.W., Davies T.D. and Tranter M. (1991) The impact of blowing snow on snow chemistry. In: Seasonal Snowpacks (edited by Davies T.D., Tranter M. and Jones H.G.), Vol. 28, pp. 71-113. Springer, Berlin.

Sigg A. (1990) Wasserstoffperoxidmessungen an Eisbohrkernen aus Grönland und der Antarktis und ihre atmosphärenchemische Bedeutung. Ph.D. thesis, University of Bern, Switzerland.

Silvente E. and Legrand M. (1995). A preliminary study of the air snow relationship for nitric acid in Greenland. Ice Core Studies of Global Biogeochemical Cycles (edited by Delmas R.J.), NATO-ASI Series, Series I: Global Environmental Change, Vol. 30, pp. 225-240. Springer, Berlin.

Steffensen J.P. (1988) Analysis of the seasonal variation in dust, $\mathrm{Cl}^{-}, \mathrm{NO}_{3}^{-}$and $\mathrm{SO}_{4}^{2-}$ in two central Greenland firn cores. Ann. Glaciol. 10, 171-177.
Tuazon E.C., Atkinson R., Plum C.N., Winer A.M. and Pitts J.N.J. (1983) The reaction of gas phase $\mathrm{N}_{2} \mathrm{O}_{5}$ with water vapour. Geophys. Res. Lett. 10, 953-956.

Wagenbach D., Graf W., Minikin A., Trefzer U., Kipfstuhl J. Oerter H. and Blindow N. (1994) Reconnaissance of chemical and isotopic firn properties on top of Berkner Island, Antarctica. Ann. Glaciol. 20, 307-312.

Wolff E. (1995). Nitrate in polar snow. Ice Core Studies of Global Biogeochemical Cycles (edited by Delmas R.J.) NATO-ASI Series, Series I: Global Environmental Change, Vol. 30, pp. 195-224. Springer, Berlin.

Yang Q., Mayewski P.A., Whitlow S., Twickler M., Morrison M., Talbot R., Dibb J. and Linder E. (1995) Global perspective of nitrate flux in ice cores. J. geophys. Res. 100 , 5113-5121. 